FOLIA SCANDINAVICA VOL. 20 POZNAŃ 2016 DOI: $10.1515 / \mathrm{fsp}-2016-0030$

$\frac{\text { DE }}{G}$ DE GRUYTER

PRESSto.

\title{
SAMMENSÆTNINGER I ET BØRNESPROGSMATERIALE
}

\author{
HENRIK JøRGENSEN \\ Aarhus Universitet
}

ABSTRACT. This article discusses compounds in a corpus collected among native and multilingual children in schools in Aarhus, Denmark. The corpus consists of interviews with individual children and recordings of groups of children playing; the compounds were collected from the interviews only. Focus is on different semantic types of compounds. A large body of the corpus consists of simple lexicalized compounds where the compound is the only relevant alternative if you want to express yourself idiomatically. Occasionally we found interesting unconventional compounding used to replace lexical gaps with the children, among the native speakers as well as among the multilingual children. In some cases, very special types of compounds came up, especially in the attempts of the children to cope with specific challenges in some of the tasks in the interviews.

\section{INTRODUKTION}

Baggrunden for denne artikel er nogle unders $\emptyset$ gelser som jeg stod som leder af i perioden 2009-12. I projektet indsamlede og undersøgte vi et materiale af forskellige mundtlige bidrag fra en gruppe børn med indvandrerbaggrund. Undersøgelsen blev til i samarbejde med Aarhus kommune, der var interesseret $\mathrm{i}$ at få vurderet hvordan forskellige skoleformer påvirkede børnenes tilegnelse af dansk sprog (se Jørgensen, 2013). I undersøgelsen indgik børn fra fire forskellige typer af skoler, fordelt på fem skoler i alt. På den ene skole var der i den klasse som vi undersøgte, en gruppe af børn uden indvandrerbaggrund; de kom til at fungere som vores kontrolmateriale, idet vi antog at deres sprogbrug kunne bruges til målestok for hvordan udviklingen forløb.

Et af de parametre som vi interesserede os for i undersøgelsen, var børnenes brug af sammensatte ord. Vi gennemgik ikke feltet nærmere, men kunne konstatere at det tilsyneladende var et felt der kunne fungere som indikator på hvor 
langt den sproglige udvikling hos de enkelte børn var nået. I dette bidrag vil jeg underkaste vores resultater fra den gang en nærmere analyse. Hvis man inddrager de mange interessante problemer som fagfeltet 'sammensætninger' rejser, bliver resultaterne svære at tolke, men der er stadig interessante pointer at hente fra materialet.

I denne artikel vil jeg først skitsere nogle af de problemer som begrebet sammensætninger rejser, og dernæst vil jeg analysere vores materiale fra dengang. I vores indsamling medtog vi alle slags sammensætninger; men her beskæftiger jeg mig af pladshensyn kun med sammensætninger der er substantiver, dvs. hvor 2. sammensætningsled er et substantiv.

\section{SAMMENSÆTNINGER: KONSTRUKTION, SEMANTIK OG PRAGMATIK}

For at kunne udnytte sammensætninger til en undersøgelse af hvor langt den sproglige udvikling hos et barn er nået, er man nødt til at skelne mellem forskellige typer af substantiver; det er ikke nok at se om der foreligger sammensætninger eller ej. Sammensætningerne i et sprog er nemlig en ret heterogen gruppe med vidt forskellige brugsbetingelser. I en del tilfælde repræsenterer sammensætningen ikke noget sprogligt valg, men er slet og ret den eneste udtryksmåde for et bestemt semantisk indhold. I andre tilfælde er der alternative udtryksformer til sammensætningen, og brugen af sammensætningen repræsenterer da et sprogligt valg. Det er de sidste der er af interesse for en vurdering af hvor avanceret børnenes sprog er.

Et tilfælde hvor sammensætningen er den eneste udtryksmulighed, er f.eks. en moderne uundværlighed som fjernsynet, hvor det normalsproglige udtryk af form er en sammensætning. I den slags tilfælde er det vanskeligt at regne sammensætningen for noget særligt i forhold til de usammensatte ord; der er ikke noget valg (med mindre man vil benytte sig af slagsudtryk, der typisk er usammensatte). Det gælder så meget mere de ganske mange tilfælde hvor et begreb nok har sit standardsproglige udtryk ved en sammensætning, men hvor en af konstituenterne er fordunklet; det gælder f.eks. ugedagene mandag, tirsdag, onsdag m.fl., eller de fleste bærformer (hindbar, kirsebar, stikkelsbar m.fl.). Her kan man tydeligt udskille andetleddet -dag, hhv. -boer, men førsteleddene er uigennemskuelige (eller i det mindste ikke-informative, som ved mange bærnavne) for en sprogbruger uden etymologisk indsigt. For en undersøgelse af om børnene har lært at bruge sammensætninger strategisk i samtalen, virker ord af disse typer ikke interessante.

Sammensætningernes status i sprogvidenskaben har været genstand for en hidsig diskussion, hvor især den kraftige udvikling af syntaktisk teori siden Noam Chomskys banebrydende indsats på dette felt har fristet morfologien med mange muligheder for at låne teori til forklaring af hvad der foregår i sammen- 
sætninger. I dansk grammatik har allerede Paul Diderichsen (1962:7) opfattet sammensætninger som syntagmatiske strukturer og regner dem ikke til det centrale morfologiske apparat. Diskussionen, som kan følges navnlig i germanistisk morfologisk forskning, ser dog ud til at være kommet frem til det synspunkt at sammensætninger først og fremmest er semantiske dannelser; den egentlige syntaks' synspunkter og metoder synes kun indirekte at kunne anvendes på materialet (Fleischer/Barz, 1992:7; Naumann, 1986:27; Motsch, 1995:1). I en sammensætning placeres to morfemer ved siden af hinanden; i dansk signaliseres dette som på tysk i det talte sprog gennem enhedstryk, dvs. morfemforbindelsen har (med få undtagelser, f.eks. forstærkende forstavelser

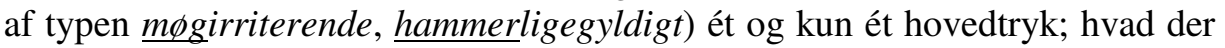
i de andre konstituenter i sammensætningen ville have været et hovedtryk, er reduceret til bitryk (Diderichsen, 1962:20, 144 ff.). I skriftsproget er signalet sammenskrivning (Diderichsen, 1962:234), et signal som dog kun håndteres konsekvent af rutinerede sprogbrugere.

Den semantik der forekommer i sammensætninger, kan med Wolfgang Motsch (1995: 4 ff.) informelt beskrives som et prædikationssystem, hvor første sammensætningsled karakteriserer særlige egenskaber ved andet sammensætningsled. Denne karakterisering kan enten finde sted via et foregangsbegreb $^{1}$ i det ene eller det andet af sammensætningsleddene, eller de to led i sammensætningen kan implicere et foregangsbegreb, som modtageren forventes at kunne indkatalysere korrekt. Sammensætninger med verber, nominaliserede verber eller adjektiver som førsteled er generelt af den første type: spisestue, tegnefilm; abstraktionsevne, konstruktionstegning; storebror, blåmejse. Sammensætninger med substantiviske forled (der ikke er afledt af foregange) er derimod af den anden type. I den slags tilfælde kræver en korrekt forståelse af sammensætningen at man indtolker den rigtige foregang; der findes nemlig ganske mange forskellige foregangstyper til indkatalysering i sammensætninger. Lad os tage et konkret eksempel: i Retskrivningsordbogens netudgave kan vi ved hjælp af baglænsfunktionen finde følgende sammensætninger med ordet "pølse" som andetled:

(1) Blodpølse, cervelatpølse, cocktailpølse, grillpølse, knækpølse, kødpølse, medisterpølse, rullepølse, smørepølse, spegep $\varnothing 1 \mathrm{se}$, s $\varnothing$ p $\varnothing \mathrm{lse}$, wienerpølse

Selv om alle disse ord er forholdsvis simple toleddede sammensætninger, viser det sig alligevel at den semantik som modtageren skal mobilisere for at forstå ordet til bunds (qualia-semantikken, sml. Pustejovsky, 1995), rummer en hel del komplikationer. Den hyppigste relation er 'lavet af'; den finder vi ved

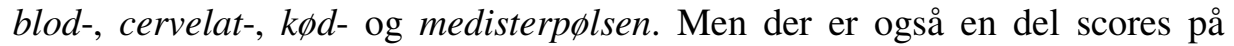

${ }^{1}$ Ordet foregang er indført af Ole Togeby $(2003: 18,201)$ som overbetegnelse for alle ordklasser med et relationelt indhold, dvs. verber, adjektiver, præpositioner og konjunktioner. 
relationer som "med henblik på" (cocktail-, grill- og smфrepфlse) eller "under anvendelse af metoden x" (rulle- og spegepølse). Endelig er der et par enkelttilfælde, der dog ikke er mere enkelttilfælde end at der sagtens kan findes paralleller: wienerpølsen er formentlig opfundet $\mathrm{i}$ Wien (relationen "hvorfra") og knækpølsen har sprødt skind (relationen "hvordan"). I materialet i eks. (1) er der ingen eksempler på en meget almindelig qualiaform ved andre sammensætninger: "af hensyn til hvem"; en tur i supermarkedet forærer sprogforskeren supplerende eksempler som børnepфlse og jagerp $\phi l s e$.

Hvor lang en liste man skal opstille for at dække alle tænkelige sammensætninger i et sprog, er et vanskeligt, hvis ikke ligefrem uafgørligt spørgsmål. Et af de tidligste eksperimenter, Herman Paul, har 10, sml. Naumann (1986:66). Derimod klarer Judith Levi sig med 9: 1) kausativ, 2) possessiv/dativisk; 3) produktiv/konstitutiv/kompositionel; 4) instrumentel; 5) essiv/appositionel; 6) lokativ (spatial/temporel); 7) formålsmæssig/benefaktiv; 8) kildemæssig/ablativisk; 9) emnemæssig (1978:77; min oversættelse). Roxana Girju og hendes kolleger derimod anfører i alt 35 (Girju et al., 2005:485). Problemet er et klassisk problem; der er ud fra et empirisk grundlag ingen afgørende kriterier for hvor mange af den slags relationer der kan etableres, og problemet modsvarer nøjagtigt vanskelighederne ved at optælle hvor mange semantiske kasus der findes. Som man vil vide, mente Charles Fillmore at det kunne gøres med 8 (Fillmore, 1968). En klassisk og meget benyttet dansk fremstilling, Ruus, 1978, når op på 15 , mens et senere forsøg på at undersøge problemfeltet, Widell, 1996, kan nøjes med tre semantiske kasus, baseret på en pragmatisk baseret semantisk metateori. Så få relationer kan man formentlig ikke beskrive de semantiske relationer mellem første- og andetleddet med; her spiller det ugunstigt ind at sammensætningerne baserer sig på flere ordklasser med meget forskellig slags semantik; som bekendt har vi i dansk substantiviske sammensætninger med mindst fem ordklasser som forled: substantiver (starekasse, bilforhandler), adjektiver (storebror, guldfisk), præpositioner (tilskud, påtår) adverbier (ford $\phi r$, bagperron) og verber (skrivemaskine, løbebånd). Allerede herigennem er spørgsmålet om en semantisk struktur blevet ganske komplekst, og jeg skal ikke forsøge at gå længere med dette teoretiske problem i denne sammenhæng. Til screeningerne af betydningsforholdene i materialet fra undersøgelsen har jeg anvendt et helt intuitivt sæt af begreber; det er ikke teoretisk fuldt tilfredsstillende, og problemet om de semantiske relationer mellem første- og andetled vil blive diskuteret sporadisk.

Ud fra et kommunikativt synspunkt er de typer af sammensætninger der indikerer at barnet kan danne deres egne konstruktioner, de interessanteste. Fra stilistikkens historie kender vi barokperiodens til tider ret krasse eksperimenter med nye og uventede sammensætninger (Albeck 1939:52 ff.), men de findes også i spontan tale. De kan siges at udgøre en kommunikativ ressource. 
Også her er der et forbehold: i visse tilfælde er der etableret en bestemt sammensætning, og det virker ikkeidiomatisk ikke at anvende den. Et af børnene i undersøgelsen anvender f.eks. et sted ordet kranieflag. Ud fra den kontekst som optagelserne har, er det oplagt at der er tale om et sфrøverflag, altså i stedet for den håndgribelige 'flag karakteriseret ved hvad det afbilder' (afbildning), nemlig et kranium, anvender standardsproget en anden semantisk relation til at beskrive denne slags flag: 'flag der er karakteriseret ved hvem der anvender det' (typisk bruger). Det er oplagt at forstå brugen af den ikkeidiomatiske sammensætning som en endnu ikke etableret indsigt i daglig sprogbrug.

Når vi taler om sammensætninger som kommunikativ ressource, er der tre distinkte brugstyper som vi må adskille. De udgør alle undertyper af den traditionelle kategori lejlighedsdannelser, men de kan adskilles fordi de har meget forskellige slags motivation; lidt populært kunne man sige at de bliver dannet til radikalt forskellige slags lejligheder. Den ene er hvad man kunne kalde sætningsanaforisk. Har man i teksten haft en sætning som "Min morfar reparede sit sommerhus $i$ flere omgange", kan man senere genoptage tråden med en sammensætning som "Disse sommerhusreparationer..." (Fossestøl, 1982:118). De sammensætninger der dannes her, er ret frie og behøver ikke at være leksikalsk veletablerede. Der ser ikke ud til at være klare eksempler på denne konstruktionstype i materialet. Jeg betegner typen som ANAFORISK SAMMENSÆTNING nedenfor.

Den anden er den fri ekspressive dannelse, hvor ord sættes sammen for at opnå særlige stilistiske effekter. I princippet er det hvad barokdigterne legede med, men de fleste kan danne den slags konstruktioner efter behov. I materialet er der en del eksempler der ser ud til at være af denne type. Jeg betegner den SOm EKSPRESSIV SAMMENSETNING nedenfor.

Endelig er der en konstruktionstype hvor den talende prøver at skyde sig ind på et begreb ved at anvende en bevidst unøjagtig sammensætning. Det sker ved hjælp af andetled som -ting eller -dims eller andre beslægtede udtryk. Udtryk af denne art gør det muligt for den talende at fastholde sin udvikling af taleturen $^{2}$ uden at blive stoppet af et manglende eller mangelfuldt begreb. Selvsagt er denne type af ord anvendelige på alle niveauer af sprogtilegnelsen; det interessante netop i forbindelse med flersprogede børn er om de har lært denne centrale ressource til at fastholde samtaleturen hos sig selv. Jeg betegner typen som APPROKSIMATIV SAMMENSÆTNING nedenfor.

Endelig er der en del lejlighedsdannelser der ikke uden videre kan henføres til nogen af disse tre typer. De betegnes nedenfor som øVRIGE LEJLIGHEDSDANNELSER.

\footnotetext{
${ }^{2}$ Begrebet TALETUR er hentet fra konversationsanalysen; med Jakob Steensigs formulering (Steensig, 2001:39, sml. Nielsen/Nielsen, 2011:35) udgør turen alt hvad folk siger fra de lukker munden op til de stopper igen for at give taleturen videre til den næste.
} 
En omhyggelig analyse af børnenes brug af sammensætninger kan derfor give en hel del informationer om deres brug af sproget. Til screeningsformål er dette sproglige område næppe det mest velegnede; dertil er der for mange komplikationer med at få stoffet fordelt over de nødvendige underkategorier. Men en gennemgang af detaljerne afslører mange interessante og tankevækkende detaljer angående børnenes sprog.

\section{OM OPTAGELSERNE}

De optagelser hvis ordforråd jeg her diskuterer, blev lavet på forskellige århusianske skoler i årene 2009-11. Generelt blev børnene interviewet i ca. 10 minutter omkring et givet emne. I første runde fik børnene forelagt 16 billeder af forskellige situationer $\mathrm{i}$ et hjem, og de blev så bedt om at fortælle ud fra dette. I anden runde spurgte vi dem om hvad der foregik i den time de var i da interviewet startede. Tredje runde havde igen udgangspunkt $\mathrm{i}$ et billedemateriale, der handlede om indkøb og varer. Børnene fik her forelagt et materiale der dels viste supermarkeder og varer heri, dels mindre forretninger. Sidste interviewrunde tog udgangspunkt $\mathrm{i}$ et ark med forskellige situationer og logoer fra fjernsynsprogrammer, såvel danske som mellemøstlige og internationale. Intentionen med billedarkene var at få børnene til at tale om emner der lå rimelig tæt på hinanden for derigennem at se hvilket ordforråd de anvendte.

Børnene blev af praktiske grunde interviewet af flere forskellige interviewere, og det er tydeligt at der er stor forskel på hvor god en kontakt interviewerne kan få med børnene. Dette betyder selvsagt en hel den for hvordan børnene performer i situationen. En anden faktor er spiller stærkt ind her, er om børnene synes om emnet eller ej. F.eks. var de generelt ikke ret interesseret i emnet om butikker, mens de til gengæld var meget begejstrede for at fortælle om fjernsyn. Da begge disse runder blev gennemført med samme interviewer i de fleste interviews, ser man tydeligt engagementet.

Interviewene blev ikke skrevet ud, men ordforrådet blev efterfølgende registreret direkte ud fra lydoptagelserne af cand. mag. Karen Hagedorn, der stod for den praktiske tilrettelæggelse af undersøgelserne. ${ }^{3}$

\section{BØRNENES ANVENDELSE AF SAMMENSÆTNINGER}

\subsection{KVANTITATIVE FORHOLD}

I optællingerne beregnedes procenten af gruppen af sammensætninger som helhed i forhold til det samlede antal substantiver. ${ }^{4}$ Måske det mest forbavsende

\footnotetext{
${ }^{3}$ Jeg er Karen Hagedorn stor tak skyldig for hendes omhyggelige gennemførelse af denne del af arbejdet.

${ }^{4}$ Frekvensen af sammensætninger er målt i forhold til mediantallet for den samlede forekomst af substantiver i hvert interview. Tallet er ikke reduceret for eventuelle gentagelser af ord. Mediantallet fremgår af denne tabel:
} 
træk ved vores observation er at procenten af sammensætninger i vores interviews med kontrolgruppen falder fra den første optagerunde til den sidste. Til gengæld stiger procenten hos de flersprogede børn, og i sidste runde ligger den højere end kontrolgruppen hos alle flersprogede børn:

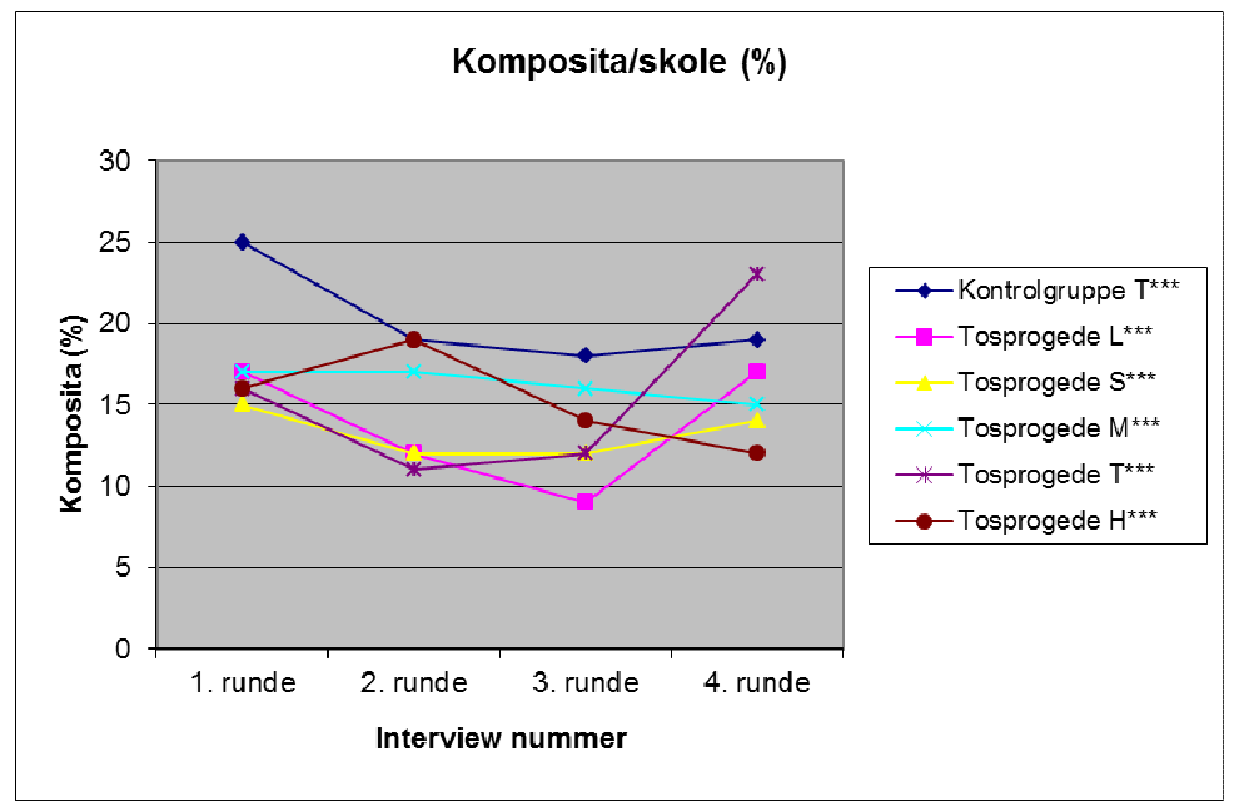

(Fig. 1) Udviklingen i antal af komposita. Skolerne er anonymiseret

Der er ikke nogen rigtig forklaring på dette. Vi har formentlig haft en progression i vores opgaver der medførte at antallet simpelt hen faldt fordi samtalen kunne håndteres uden. Alene af den grund er sammensætninger som helhed ikke nogen specielt interessant faktor. En anden grund kan være at børnene bliver socialiseret til en mindre kreativ sproglig adfærd i løbet af den første skoletid. Det kan vi heller ikke præcist påvise, men det er tydeligt når man lytter til interviewene, at børnene bliver mindre fabulerende og mere orienteret mod at respondere præcist på udfordringen i samtalen. Alene af den grund bliver der

\begin{tabular}{lllll}
\hline Skole & Interview 1 & Interview 2 & Interview 3 & Interview 4 \\
\hline Kontrolgruppe & 56 & 60 & 58,8 & 60 \\
\hline $\mathrm{T}^{* * * *}$ & 45,5 & 45,5 & 45,5 & 54 \\
\hline $\mathrm{L}^{* * * *}$ & 46,5 & 35,5 & 39 & 46 \\
\hline $\mathrm{S}^{* * *}$ & 44,5 & 37 & 45,5 & 54 \\
\hline $\mathrm{M}^{* * *}$ & 34 & 42 & 47 & 54 \\
\hline $\mathrm{H}^{* * *}$ & 52 & 54 & 43 & 59 \\
\hline
\end{tabular}


betydelig færre anledninger for dem til at benytte kreative indfald som kranieflag som jeg nævnte højere oppe.

\subsection{IKKELEKSIKALISEREDE OG LEKSIKALISEREDE SAMMENSÆTNINGER}

Den langt overvejende del af materialet er som sagt leksikaliserede sammensætninger der ikke kan overraske nogen. Det hænder dog ikke sjældent at nogle af disse sammensætninger optræder i samspil med andre ord på en meget signifikant måde. Blot et enkelt eksempel: På billedarket til første runde sås to børn. De skulle helt klart forstås som 'børnene i huset', men der var en tydelig forskel på hvilke ord vore to børnegrupper anvendte på dem. Børnene fra stampopulationen brugte de usammensatte udtryk pigen og drengen, mens de tosprogede børn anvendte sammensatte udtryk: stores $\phi$ ster - lilles $\phi$ ster storebror - lillebror. Der ligger næppe nogen større sprogsystematisk visdom i dette. Børn i stampopulationen vokser sjældent op i familier med mere end tre børn, og de har derfor sjældent anledning til at anvende den flervejsmulighed som matrixen stor-/lille-søster/bror tilbyder. Det modsatte er tilfældet blandt de flersprogede børn. På et senere tidspunkt i optagelserne opdagede vi at stampopulationsbørnene nu også anvendte de familieorienterede udtryk; vi kan ikke give nogen god grund, andet end at de vagere udtryk pigen og drengen ikke mere rakte til hvad de ville give udtryk for i forbindelse med de nye opgaver i interviewene.

I det leksikaliserede ordmateriale fandt vi også en del tilfælde hvor de tosprogede børn anvendte sammensatte ord på en måde der sådan set ikke stred mod den eksplicitte semantik, men nok mod leksikaliseringen. Det var billedet af en køjeseng der lokkede dem på glatis; den blev f.eks. betegnet dobbeltseng, og en dobbelt seng er en køjeseng jo unægtelig, uanset at ordets leksikalske indhold er en ganske anden. Et andet barn forsøgte sig med ordet haengek $\phi j e$; her er det formentlig ordet køje der skaber overgangen. I fjerde optagerunde hørte vi ordet bangehed, der er dannet perfekt efter reglerne og bestemt er et brugbart ord; men så længe det usammensatte ord angst er i omløb, kommer det nye ord nok ikke så langt.

\subsection{ANAFORISKE, EKSPRESSIVE, OG APPROKSIMATIVE SAMMENSÆTNINGER}

For en forståelse af sammensætninger som ressource er der tre vigtige undergrupper som jeg her vil behandle nærmere: de ANAFORISKE, de EKSPRESSIVE og de APPROKSIMATIVE sammensætninger.

De anaforiske sammensætninger ser ikke ud til at forekomme i materialet, hverken hos den ene eller den anden gruppe af børn. Dette sproglige virke- 
middel er givetvis bundet til relativt skriftsprogsagtige sammenhæng, og det er derfor ikke meget sandsynligt at børnene har brug for at udtrykke sig sådan. Her kan kun en tæt gennemgang af interviewene vise om der alligevel skulle foreligge noget, men der er ingen af de indsamlede ord der entydigt peger i den retning.

De ekspressive sammensætninger er der derimod en del af. En køjeseng er - især fra børnehøjde - en høj seng, og ét af de flersprogede børn anvender derfor ordet højseng om tingen. Børnene fra stampopulationen er godt med på dette felt; i fjerde runde præsterer de f.eks. agentmaster, fantasimenneske og hjerneskylning i forbindelse med deres fjernsynsoplevelser. I en del tilfælde skal det pointeres at der i situationen er tale om feminine personer eller dyr; her finder vi ord som pigekat eller tøsepige anvendt af flersprogede børn. Samme tendens til det ekspressive ligger givetvis bag ordet parykhår i et interview med et flersproget barn.

Den interessanteste og bedst repræsenterede gruppe er de approksimative sammensætninger. I de tidligste optagelser, hvor børnene går i 1. klasse, er det næste kun stampopulationsbørnene der kan bruge denne konstruktionsmåde. Det er f.eks. dem der leverer særprægede orddannelser som en nikkedyrsting (i forbindelse med nogle tøjdyr på billedarket). I en senere runde finder vi ord af samme art: bippeting (et stykke legetøj der kan bippe), dimsedutnoget (også om et stykke legetøj) og legetøjsdimsedut. Endelig i en sammenhæng hvor der er tale om et fænomen der ligner en regnbue, leverer et af børnene ordet regnbueting. Som man kan se, er det typiske at førsteleddet fokuserer på en typisk aktivitet eller en genstand der kan fungere som lighedsmarkør, mens andetleddet er et substantiv med meget vidt scope af mulige referenter. På den måde får ordet sin kommunikative værdi ved at pege på en prototypisk egenskab og en vid kategori sådan at modtageren med lidt held kan skyde sig ind på hvilken slags genstand afsenderen mener.

Det er selvfølgelig en vigtig ressource at kunne skyde sig ind på ting man gerne vil tale om, uanset at man ikke lige har en korrekt betegnelse for dem på det mentale lager. I vores materiale kan vi se at de flersprogede børn ikke rigtig kan levere den slags eksempler i de første optagerunder. Men i tredje optagerunde (hvor børnene gik i anden klasse) kan de flersprogede på én af skolerne bruge approksimative ord som madting, ligesom ordet dimsedut (der nok i en eller anden forstand er en sammensætning) også optræder. På en anden skole betegner et af børnene et supermarked som et Føtexsted, formentlig også en approksimativ konstruktion. Endelig i den fjerde runde af optagelser (hvor børnene var i andet halvår af andet skoleår) har vi udtryk som fodboldting og karateting, hvor vi ser hvordan børnene bruger sammensætningerne strategisk til at tilnærme sig et begreb; de vil ikke bare tale om sportsgrenene som sådan, men udvisker begreberne ved hjælp af sammensætningen for at få mere af sammenhængen omkring selve spillet med. 


\subsection{SEMANTISKE TYPER - FORSKELLE BLANDT BRUGERGRUPPERNE?}

Med alle de forbehold som man kan tage over for en rent semantisk intuitiv klassifikation af sammensætninger, er det alligevel interessant at se hvordan sammensætningerne fordeler sig mellem stampopulation og flersprogede børn. Denne undersøgelse har jeg af praktiske grunde kun gennemført for det ordstof der er indsamlet i første runde, altså da børnene er ca. 7 år gamle og lige er begyndt i skolen. Første sammensætningsled betegnes FS1, andet sammensætningsled betegnes FS2.

Klart den vigtigste relation i materialet for begge grupper er FORMÅL, forstået således at formålet med FS2 både kan være at kunne gennemføre den aktivitet der udtrykkes i FS1 (førsteleddet er altså et verbum), og at opnå, fastholde eller frembringe den genstand der udtrykkes i FS1. Til den første gruppe regner jeg ord som badekar, hyggekrog og liggestol. Til den anden hører ord som hovedpude, kaffekande og blyantspidser. Der er lidt flere af den slags ord hos de flersprogede børn, men det mest påfaldende er at hvor stampopulationens børn væsentligst bruger ord der relaterer sig ret tæt til billedarket, kommer de flersprogede børn langt videre omkring: flyvemaskine, legeland og rutschebane, for nu at tage nogle genstande, som i hvert fald ikke fandtes på billedforlægget.

En anden meget omfattende ordgruppe er dem hvor FS1 er et substantiv eller et verbum der indholdsmæssigt specificerer FS2. Man kan inddele denne gruppe i flere undergrupper; f.eks. kan FS1 være et karakteristisk element (havregr $\phi d$ ), en karakteristisk funktion (tegnefilm), en speciel egenskab (lillebror, dobbeltseng, sortbande), et særligt tidspunkt (julegave, morgenmad), et foretrukkent objekt (børnelokker) eller et specifikt fremstillingsredskab (pandekage) - og der er mange andre undertyper. Igen ser billedet ud til at være at de flersprogede børn kommer længst omkring og forholder sig mest kreativt til forlægget. Det er dem der præsterer specielle ord af typen diddlarmbånd, børnelokker, fastelavnst $\phi j$ og diskokugle, alt sammen ord som på ingen måde er givne ud fra billedforlægget. Præstationerne på stampopulationens side er påfaldende mere tamme og holder sig mere til hvad billederne umiddelbart viser. ${ }^{5}$

I samtalen om tegningerne har begge grupper af børn det ganske vanskeligt med hvad vi må antage skal være et tøjdyr af form som en ugle. Ingen af børnene har nemt at udtrykke hvordan tingen skal kategoriseres. Der er børn i begge grupper der kalder væsnet en bamseugle, og et flersproget barn anvender også dukkeugle. Derudover forekommer ordet uglepude hos et flersproget barn, ligesom et af børnene fra stampopulationen anvender udtrykket en leopardbamse. 'Bamse' fungerer her som overbegreb for tøjdyr i det hele taget, og 'dukke' bruges på samme måde til at angive afbildningsrelationen der er ikke tale om en levende ugle, men om en afbildning. Fænomenet er

\footnotetext{
${ }^{5}$ Af copyrightmæssige grunde kan billedforlægget uheldigvis ikke gengives her.
} 
interessant, eftersom alle tre sammensætninger ville kunne vendes om og stadig bruges om den samme genstand: uglebamse, ugledukke, bamseleopard og til nød også pudeugle. Det er ikke almindeligt; en stuefugl er bestemt ikke en fuglestue; men lige præcis den semantiske relation hvor et substantiv angiver eksistensmodus for et andet substantiv, gør det muligt. Et flersproget barn anvender et sted ordet pigekat i betydningen 'hunkat', og også her kan ordet vendes om: kattepige 6 (ligesom kattehun også ville være anvendelig).

Da der er langt flere flersprogede børn i undersøgelsen (ca. 45) end børn fra stampopulationen (ca. 10-11) $)^{7}$, er der selvsagt også indsamlet langt flere sammensætninger fra de flersprogede børn. Hvis man fordelte ordene pr. barn, ville der stadig være flere sammensætninger pr. barn i stampopulationen. Ser man på ordstoffet som det foreligger, er der for det første flere sammensatte ord fra de flersprogede børn, og de ord de anvender, opviser også en lang række semantiske relationer som ikke forekommer i materialet fra stampopulationen. Jeg antager at dette er ganske typisk for den tilfældighedsfaktor som ganske givet er et vilkår i al forskning i et lukket specialkorpus; især fordi en del af flersprogede børn er meget kreative, kommer de faktisk ret langt omkring i brugen af sammensætninger.

Et ganske særligt problem er de mange engelske låneord, som børn i 7-8 års alderen næppe klart opfatter som sammensatte, selv om de i prosodisk forstand fungerer på samme måde. Det drejer sig om ord som makeup, milkshake, playstation, pomfritter $^{8}$ og mange flere. I denne sammenhæng er ordene blevet registreret $\mathrm{i}$ indsamlingen, men de bør nok betragtes som udelelige leksikalske enheder i dansk, i hvert fald foreløbig. På den anden side kan det sagtens tænkes at de med tiden bliver delelige og kommer til at indgå symbioser med danske homonymer. Det er i hvert fald ganske interessant at se hvor mange ord der allerede nu er af denne type; de præger på godt og ondt det dansk som de flersprogede børn betjener sig af. Vi har ikke undersøgt udtalen af disse ord, men præcis her kunne der ligge et meget interessant forskningsemne. Det er ganske givet at de ikke udtales på formfuldendt engelsk; tværtimod ville det være interessant at se hvordan de tilpasses danske udtalekonventioner.

\section{KONKLUSION}

Som man kan se, er der ganske interessante pointer at hente $i$ en analyse af det sammensatte ordstof i interviewene med børnene fra de to grupper. Selv om ordstoffet ikke uden videre kan ses som en indikator på en sproglig udvikling,

\footnotetext{
${ }^{6}$ Ordet kattepige vil dog nok oftest blive forstået som 'en pige der minder om en kat', altså i semantisk henseende en metaforisk relation, snarere end en væsensidentitetsfunktion.

${ }^{7}$ Tallene varierer alt efter hvor mange børn der var i skole på de dage hvor vi optog. Vi gjorde af praktiske grunde ikke nogen fors $\emptyset \mathrm{g}$ på at lave efterindsamlinger.

8 Denne stavemåde findes i Retskrivningsordbogen sammen med den etymologisk orienterede pomme frite, der ser helt ynkelig ud i singularis.
} 
kan man, hvis man går ned i underkategorierne, tydeligt se en række interessante fænomener der indikerer i hvilken retning den sproglige udvikling løber.

I denne artikel har jeg ikke beskæftiget mig med de forskelle mellem de enkelte skoler som vi kunne aflæse af undersøgelserne, men i stedet taget de flersprogede børn under ét. Det er imidlertid ikke noget retvisende billede. Når man går dybere ned i materialet, kan man meget tydeligt se forskellen mellem de børnegrupper der befandt sig på skoler med næsten kun flersprogede børn, og så de flersprogede børn der gik på skoler hvor stampopulationen udgjorde en mere eller mindre massiv majoritet. Det var også tydeligt aflæseligt af andre dele af vores materiale på hvilke skoler der fandtes sprog som børnene kunne bruge til parallel kommunikation (det drejede sig om arabisk og kurdisk), og hvor børnene var nødt til at bruge dansk i alle situationer i skolen, også over for kammerater med et andet hjemmesprog fordi de kun havde dansk fælles. Disse forskelle kan delvis aflæses i sammensætningerne. Den mest kreative anvendelse af sammensætninger forekom nemlig på den skole hvor der kun gik flersprogede børn med klare parallelsprog. I projektet fandt vi ikke nogen rigtig plausibel forklaring på denne observation.

\section{LITTERATURHENVISNINGER}

Albeck, U. (1939). Dansk Stilistik. København: Gyldendalske Boghandel.

Diderichsen, P. (1962). Elementar dansk Grammatik. København: Gyldendal.

Fillmore, C. (1968). The Case for Case. In E. Bach, R. Harms (red): Universals in Linguistic Theory (1-88). New York: Holt, Rinehart \& Winston.

Fleischer, W., Barz, I. (1992). Wortbildung der deutschen Gegenwartsprache. Tübingen: Max Niemeyer Verlag.

Fossestøl, B. (1982). Tekstlingvistikk - en ny synsvinkel? Bindingsverket i tekst. Oslo, Bergen, Stavanger, Troms $\varnothing$ : Universitetsforlaget.

Girju, R. (et al). (2005). On the semantics of noun compounds. Computer Speech and Language 19 (2005), 479-496.

Jørgensen, H. (2013). Wie beeinflusst die Schulform den Spracherwerb zweisprachiger Kinder? In: I. Bartoszenicz et al. (red.), Sprache - Literatur - Kultur im germanistischen Gefige: Sprachwissenschaft im Fokus germanistischer Forschung und Lehre (s. 407-421). Wroclaw \& Dresden: Neisse Verlag.

Levi, J. (1978). The syntax and semantics of complex nominals. New York, San Francisco, London: Academic Press.

Motsch, W. (1995). Deutsche Wortbildung in Grundzügen. Berlin \& New York: Walter de Gruyter.

Naumann, B. (1986). Einführung in die Wortbildungslehre des Deutschen. Tübingen: Max Niemeyer Verlag.

Nielsen, M.F., Nielsen, S.B. (2001). Samtaleanalyse. Frederiksberg: Samfundslitteratur.

Pustejovsky, J. (1995). The generative lexicon. Cambridge, Mass. \& London: MIT Press.

Ruus, H. (1978). Sproglig betydningsanalyse. Semantiske roller I tekster. Nydanske Studier \& Almen kommunikationsteori. 10-11 (1978), 161-197.

Steensig, J. (2001). Sprog i virkeligheden: Bidrag til en interaktionel lingvistik. Århus: Aarhus Universitetsforlag.

Togeby, O. (2003). Fungerer denne satning? København: G.E.C. Gad. 
Widell, P. (1996). Aspektuelle verbalklasser og semantiske roller - Den dobbelte aspektkalkule. In: L. Schack Rasmussen (red.), Semantiske roller $=$ Odense Working Papers in Language and Communication 10, 135-168.

\section{APPENDIKS: LISTE OVER SAMMENS ETNINGER FRA 1. INTERVIEWRUNDE}

Tosprogede børn
actionfilm
aftensmad
badekar (om
brusekabine)
badekar
badeværelse
bamseugle (2 børn)
bærbar
bedstemor
blyantspidser
bogstav
børnehjem
børnekanal
børnelokker
børneværelse
brusebad
bussemand
cornflakes
danskbog
diddlarmbånd
diskokugle
dobbeltseng (om
køjeseng)
dobbeltseng
dobbeltsofa
dukkeugle
edderkop
fastelavnstøj
fjernsyn
flyvemaskine
fodbold
fodboldspiller
forældre
fortand
frikvarter
ghettoblaster
glaskop
grønbande
grøntsager
gta
gudmor
gymnastiktøj
håndklæde

\begin{tabular}{|c|c|}
\hline håndvask & rister \\
\hline havregrød & rulleskøjte \\
\hline havregryn & rumskib \\
\hline hængekøje & rutschebane \\
\hline heksehat & saftevand \\
\hline højseng & skoletaske \\
\hline ingenting & skoleting \\
\hline internet & skraldespand \\
\hline jetfly & skrivebord \\
\hline julegave & slåskamp \\
\hline kaffekande & sodavand \\
\hline kanariefugl & sortbande \\
\hline kæledyr & soveværelse \\
\hline kodelås & spiserum \\
\hline kogeplade & stikbold \\
\hline køjeseng & storebror \\
\hline kung fu & storesøster \\
\hline kyllingesuppe & strømpebukser \\
\hline legeland & stuebord \\
\hline legetøj & svømmehal \\
\hline lillebror & teenager \\
\hline lillesøster & tegnefilm \\
\hline lommelygte & tekande \\
\hline madpakke & tekop \\
\hline make-up & tekop (om en tekande) \\
\hline marsvin & toiletvask \\
\hline middag & tørklæde \\
\hline milkshake & træstamme \\
\hline morgenbrød & tv \\
\hline morgenmad & uglepude \\
\hline mormor & underbukser \\
\hline Nintendo DS & vandhane \\
\hline pandekage & vaskemaskine \\
\hline papegøje & y8 \\
\hline penalhus & yndlingsmad \\
\hline pigekat & \\
\hline pigespil & Kontrolgruppe \\
\hline playstation & \\
\hline playstation 3 & aftensmad \\
\hline playstation & badekar \\
\hline pomfrittes & badeværelse \\
\hline popcorn & bamseugle \\
\hline popcorn (om & båndoptager \\
\hline morgenmadsprodukt) & børnetime \\
\hline risengrød & brødholder \\
\hline
\end{tabular}




brusebad
Colabjørn (Koalabjørn?)
drengeting
drengeværelse
farfar
farmor
farveblyant
fjernsyn
forældre
forhæng
gæsteværelse
grøntsagssuppe
guldfisk
gulvtæppe
håndklæde
håndvask
havregrød
hovedpude
hyggekrog
hyggestuen
kaffekande
køjeseng
køkkenvask

komfurplade
kontorstol
lampeting
legesager
leopardbamse
liggestol
lillebror
lillesøster
maddag
MGP
missekat
morfar
morgenmad
mormor
nikkedyr
nikkedyrsting
pigeværelse
popcorn
risengrød
rumkrig
skoleting
skrivebord
slikpose

sofaseng sommerfugl sommerhus sovedyr soverum spisestue sportsmusik ståbænk storebror storesøster sugekop tegnefilm tegnepapir tegneserie tekande tomatsuppe vandhane vandkande vækkeur vingummi yndlingsfilm

\section{Henrik Jørgensen}

Institut for Kommunikation og Kultur

Afdeling for Nordisk, Vikingestudier og Oplevelses $\emptyset$ konomi

Jens Chr. Skous Vej 2

DK-8000 Aarhus C

Danmark

norhj@cc.au.dk 